Sains Malaysiana 49(12)(2020): 2963-2975

http://dx.doi.org/10.17576/jsm-2020-4912-08

\title{
Hubungan antara Cahaya Matahari dengan Penggunaan Sel Suria Generasi Ke-3 Menurut Al-Quran
}

(The Relationship between Sunlight and the Use of 3rd Generation Solar Cells According to the Qur'an)

\author{
Muhammad Hilmi Jalil, Siti Nur Farhana Mohd Nasir, Mohammad IKhwan Ismail, Mohd Yusof Haji \\ OTHMAN* \& MOHD ASRI MAT TERIDI
}

\begin{abstract}
ABSTRAK
Bahan api fosil yang lazim digunakan pada hari ini sebagai sumber tenaga memerlukan kos yang tinggi, mencemarkan alam sekitar dan akan habis pada masa akan datang. Salah satu sumber tenaga pilihan yang dapat menggantikan sumber tenaga fosil adalah tenaga yang dihasilkan oleh matahari. Justeru makalah ini membincangkan ilmu al-Qur'an yang berkaitan dengan tabii matahari, khususnya tentang sumber tenaga yang terhasil daripada kewujudan matahari. Makalah ini juga membincangkan integrasi antara ilmu al-Qur'an dengan sains dalam konteks penggunaan tenaga matahari. Perbincangan ini dikaitkan dengan penggunaan sel suria generasi ke-3 iaitu sel suria terpeka pewarna, sel suria organik dan sel suria perovskit. Kajian ini mendapati al-Quran menganjur manusia melakukan kajian tentang matahari, supaya manusia beroleh manfaat daripada matahari, dan dalam masa yang sama mengelak daripada mendapat kesan negatif daripada matahari. Antara manfaat matahari yang dinyatakan dalam al-Quran adalah penghasilan sumber tenaga yang boleh diperbaharui. Kegagalan manusia memahami tabii matahari dengan baik akan menyebabkan manusia ketinggalan dan gagal memanfaatkan nikmat Allah yang menciptakan matahari secara komprehensif.
\end{abstract}

Kata kunci: Al-Qur'an; matahari; sel suria organik (OSC); sel suria perovskit (PSC); sel suria terpeka pewarna (DSSC)

\section{ABSTRACT}

Fossil fuels commonly used today as a source of energy is costly, polluted the environment and will be depleted in the future. One of the preferred sources of energy that can replace fossil fuels is solar-generated energy. Thus, this paper discusses the knowledge of Qur'an related to sunlight, in particular the source of energy generated by the existence of the sun. This paper also discusses the integration of Qur'an and science in the context of solar energy generation. The discussion relates to the use of $3^{\text {rd }}$ generation solar cells namely dye-sensitized solar cells, organic solar cells and perovskites solar cells. The study found that the Qur'an encourages people to study the sun, so that they can benefit from the sun, while at the same time avoiding the negative effects of the sun. One of the benefits of the sun mentioned in the Qur'an is the generation of renewable energy sources. Failure to understand the sun properly will cause humans fail to fully utilize the favour of God who created the sun in a comprehensive manner.

Keywords: Al-Qur'an; dye-sensitized solar cells (DSSCs), organic solar cells (OSCs), perovskite solar cells (PSCs); solar energy

\section{PENDAHULUAN}

Sains adalah ilmu yang berhubung dengan bagaimana manusia memahami tabii alam jasmani secara sistematik, mantik dan objektif dengan kaedah tertentu yang dibuat sedemikian rupa sehingga dapat menumpukkan pengetahuan yang boleh dipercayai (Medawar 1987; Zain 2000). Manakala teknologi adalah ilmu teknik yang digunakan oleh ahli sains untuk memanfaat alam jasmani setelah tabiinya difahami. Kedua-dua ilmu sains dan ilmu teknologi saling diperlukan oleh manusia dalam usaha untuk memakmurkan alam ini.
Al-Qur'an adalah himpunan ilmu wahyu yang didatangkan oleh Allah S.W.T. sebagai panduan untuk hidup manusia di alam ini sebagaimana yang dinyatakan dalam surah al-Baqarah (2); ayat 2 yang bermaksud,

'Kitab al-Qur'an ini, tidak ada sebarang syak padanya (tentang datangnya daripada Allah dan tentang sempurnanya); ia pula menjadi petunjuk bagi orang-orang yang (hendak) bertaqwa'

Al-Qur'an diturunkan kepada Rasulullah SAW antara tahun 610 hingga 632. Dalam al-Qur'an terdapat banyak ayat yang menerangkan tentang fenomena alam 
tabii. Dianggarkan terdapat sekitar 750 ayat al-Qur'an yang berhubung secara langsung dengan prinsip dan falsafah alam tabii (Abdus Salam 1995). Terdapat ayat yang berhubung dengan fenomena kejadian manusia (alHajj (22); 5) yang bermaksud:

'Wahai umat manusia, sekiranya kamu menaruh syak (ragu-ragu) tentang kebangkitan makhluk (hidup semula pada hari kiamat), maka (perhatilah kepada tingkatan kejadian manusia) kerana sebenarnya Kami telah menciptakan kamu dari tanah, kemudian dari setitik air benih, kemudian dari sebuku darah beku, kemudian dari seketul daging yang disempurnakan kejadiannya dan yang tidak disempurnakan; (Kami jadikan secara yang demikian) kerana Kami hendak menerangkan kepada kamu (kekuasaan Kami); dan Kami pula menetapkan dalam kandungan rahim (ibu yang mengandung itu) apa yang Kami rancangkan hingga ke suatu masa yang ditentukan lahirnya; kemudian Kami mengeluarkan kamu berupa kanak-kanak; kemudian (kamu dipelihara) hingga sampai ke peringkat umur dewasa; dan (dalam pada itu) ada di antara kamu yang dimatikan (semasa kecil atau semasa dewasa) dan ada pula yang dilanjutkan umurnya ke peringkat tua nyanyuk sehingga ia tidak mengetahui lagi akan sesuatu yang telah diketahuinya dahulu. Dan (ingatlah satu bukti lagi); Engkau melihat bumi itu kering, kemudian apabila Kami menurunkan hujan menimpanya, bergeraklah tanahnya (dengan tumbuh-tumbuhan yang merecup tumbuh), dan gembur membusutlah ia, serta ia pula menumbuhkan berjenis-jenis tanaman yang indah permai. '

Terdapat juga ayat yang berhubung dengan kejadian bumi dan langit (al-Baqarah (2); 22) yang bermaksud,

'Dia lah yang menjadikan bumi ini untuk kamu sebagai hamparan, dan langit (serta segala isinya) sebagai bangunan (yang dibina dengan kukuhnya); dan diturunkan-Nya air hujan dari langit, lalu dikeluarkanNya dengan air itu berjenis-jenis buah-buahan yang menjadi rezeki bagi kamu; maka janganlah kamu mengadakan bagi Allah, sebarang sekutu, padahal kamu semua mengetahui (bahawa Allah ialah Tuhan Yang Maha Esa).'

Allah S.W.T. juga menyatakan tentang kejadian bintang yang dapat digunakan oleh manusia sebagai panduan untuk perjalanan mereka sebagaimana yang dinyatakan dalam ayat dalam surah al-Nahl (16); 16, yang bermaksud,

'Dan (Ia mengadakan) tanda-tanda panduan jalan, dan dengan bintang-bintang (pada waktu malam) mereka dapat mengetahui arah yang hendak dituju.'

Allah S.W.T. juga menerangkan tentang asal usul kejadian alam semesta dan alam kehidupan di dunia ini sebagaimana firman-Nya (al-Anbiya (21); 30), yang bermaksud,

'Dan tidakkah orang-orang kafir itu memikirkan dan mempercayai bahawa sesungguhnya langit dan bumi itu pada asal mulanya bercantum (sebagai benda yang satu), lalu Kami pisahkan antara keduanya? Dan Kami jadikan dari air, tiap-tiap benda yang hidup? Maka mengapa mereka tidak mahu beriman?'
Allah S.W.T. juga menjelaskan tentang kegunaan sebahagian daripada alam jasmani yang dijadikan-Nya untuk membantu manusia di alam ini sebagaimana firman-Nya (Yaasin (36); 71-73), yang bermaksud,

'Tidakkah mereka melihat dan memikirkan, bahawa Kami telah menciptakan untuk mereka binatang-binatang ternak, di antara jenisjenis makhluk yang telah Kami ciptakan dengan kekuasaan Kami lalu mereka memilikinya?'

'Dan Kami jinakkan dia untuk kegunaan mereka; maka sebahagian di antaranya menjadi kenderaan mereka, dan sebahagian lagi mereka makan.'

'Dan mereka beroleh berbagai faedah dan kegunaan pada binatang ternak itu dan juga beroleh minuman; maka mengapa mereka tidak mahu bersyukur?'

Kesemua fenomena yang dinyatakan oleh al-Qur'an tersebut menuntut manusia untuk melihat, meneliti, mengkaji dan seterusnya menikmati segala macam nikmat daripada fenomena alam tabii tersebut (Ahmad Sunari 2009). Salah satu penciptaan yang banyak disentuh oleh al-Qur'an adalah tentang penciptaan matahari serta fungsinya untuk manfaat manusia. Penciptaan matahari yang diterangkan oleh al-Qur'an, menuntut manusia untuk melihat dan berfikir tentang ciriciri dan sifat tabii matahari. Setelah memahami tabiinya, manusia dapat mengambil manfaat daripada penciptaan alam tersebut.

Kertas ini membincangkan fenomena dan tabii matahari sebagaimana yang diterangkan dalam alQur'an. Oleh yang demikian sumber utama dan rujukan dalam menulis kertas ini diperoleh daripada sumber yang berwibawa dalam Islam, iaitu al-Qur'an yang disahkan oleh Jabatan Kemajuan Islam Malaysia (Abdullah Basmeih 2010). Selain itu, beberapa pandangan sarjana berkaitan matahari juga turut dirujuk.

KEPENTINGAN MATAHARI DARI PERSPEKTIF AL-QUR'AN Allah S.W.T. memaklumkan kepada kita ciri sinaran cahaya matahari sebagaimana dinyatakan dalam surah Yunus (10); ayat 5, yang bermaksud,

'Dia-lah yang menjadikan matahari bersinar-sinar (terang-benderang) dan bulan bercahaya, dan Dia-lah yang menentukan perjalanan tiaptiap satu itu (berpindah-randah) pada tempat-tempat peredarannya masing-masing) supaya kamu dapat mengetahui bilangan tahun dan kiraan masa. Allah tidak menjadikan semuanya itu melainkan dengan adanya faedah dan gunanya yang sebenar. Allah menjelaskan ayatayat-Nya (tanda-tanda kebesaran-Nya) satu persatu bagi kaum yang mahu mengetahui (hikmat sesuatu yang dijadikan-Nya).'

Dalam ayat ini Allah S.W.T. menyatakan matahari bersinar kerana ia menjana cahaya dan mengeluarkan sinaran. Cahaya daripada matahari terjana kerana 
berlakunya tindak balas nuklear di bahagian teras matahari berkenaan yang suhunya sekitar 15 juta K (unit asas suhu) atau $1.5 \times 10^{7} \mathrm{~K}$. Suhu di permukaan matahari pula adalah sekitar $5760 \mathrm{~K}$. Teras matahari terlalu padat dengan daya gravitinya yang amat tinggi $\left(\mathrm{g}=2.7398 \times 10^{12}\right.$ $\mathrm{ms}^{-2}$ ) dengan tindak balas nuklearnya berantai yang menukar nuklues hidrogen menjadi nukleus helium. Proses penyepaian nukleus daripada hidrogen kepada helium ini mengeluarkan tenaga yang amat banyak. Tenaga nuklear ini merupakan sumber utama tenaga matahari. Tenaga yang dipancarkan keluar daripada matahari untuk setiap meter persegi dapat dihitung dengan mengandaikan matahari sebagai bebola hitam yang panas. Amaun tenaga yang dipancarkan adalah $6.4 \times 10^{7} \mathrm{Wm}^{-2}$. Jarak purata bumi-matahari pula adalah $\left(1.5 \times 10^{11} \mathrm{~m}\right)$. Sekiranya dilakukan perhitungan dengan mengandaikan sinaran matahari mengikuti taburan BoseEinstein, tenaga sinaran matahari yang sampai ke bumi untuk setiap meter persegi adalah $1352 \mathrm{Wm}^{-2}$. Maknanya setiap meter persegi di permukaan bumi mendapat tenaga sebanyak $1352 \mathrm{~W}$ daripada matahari secara berterusan dan percuma. Tenaga matahari inilah yang menjana segala aktiviti kehidupan di bumi melalui proses fotosintesis, memberi cahaya, memberi haba dan meruwapkan air untuk menjadi hujan. Dalam ayat ini Allah S.W.T. menyatakan "Dia-lah yang menjadikan matahari bersinar-sinar (terang-benderang)”, yang memungkinkan segala aktiviti di bumi berlaku.

Cahaya matahari terdiri daripada foton yang apabila menimpa permukaan daun yang terdapat stomata boleh berlakunya proses fotosintesis yang menyebabkan tumbuh-tumbuhan hidup. Dalam proses fotosintesis ini gas oksigen dihasilkan dan gas karbon dioksida diserap dalam stomata. Gas oksigen amat penting kepada manusia dan haiwan kerana mereka memerlukan udara (oksigen) untuk proses pernafasan. Pada masa yang sama, mereka juga membebaskan karbon dioksida sebagai bahan kumbahan. Sebahagian besar oksigen yang diperlukan oleh manusia dan haiwan untuk pernafasan datangnya daripada tumbuh-tumbuhan. Proses penghasilan oksigen pada tumbuhan dinyatakan Allah S.W.T. dalam surah anNur (24), ayat 35, yang bermaksud,

'Allahyang menerangi langit dan bumi. Bandingan nur hidayah petunjuk Allah (Kitab Suci al-Qur'an) adalah sebagai sebuah "misykaat" yang berisi sebuah lampu; lampu itu dalam geluk kaca (qandil), geluk kaca itu pula (jernih terang) laksana bintang yang bersinar cemerlang; lampu itu dinyalakan dengan minyak daripada pokok yang banyak manfaatnya, (iaitu) pokok zaitun yang bukan sahaja disinari matahari semasa naiknya dan bukan sahaja semasa turunnya (tetapi ia sentiasa terdedah kepada matahari); hampir-hampir minyaknya itu - dengan sendirinya - memancarkan cahaya bersinar (kerana jernihnya) walaupun ia tidak disentuh api; (sinaran nur hidayah yang demikian bandingannya adalah sinaran yang berganda-ganda): cahaya berlapis cahaya. Allah memimpin sesiapa yang dikehendaki-Nya (menurut undang-undang dan peraturan-Nya) kepada nur hidayah-Nya itu; dan Allah mengemukakan berbagai-bagai misal perbandingan untuk umat manusia; dan Allah Maha Mengetahui akan tiap-tiap sesuatu.'
Dalam ayat ini Allah S.W.T. menyebut '(iaitu) pokok zaitun yang bukan sahaja disinari matahari semasa naiknya dan bukan sahaja semasa turunnya (tetapi ia sentiasa terdedah kepada matahari)'. Pokok zaitun yang disinari matahari akan memindahkan tenaga matahari kepada pokok berkenaan dan menyebabkan pokok zaitun tersebut membesar dalam proses 'fotosintesis'. Proses fotosintesis ini ditemui oleh Jan (John) Ingenhousz atau Ingen-Housz FRS (1730-1799), yang merupakan ahli sains Belanda pada tahun 1779. Beliau mendapati cahaya matahari (yakni foton) merupakan unsur utama dalam proses fotosintesis yang menyebabkan tumbuhan hijau menyerap karbon dioksida dan melepaskan oksigen (Magiels 2010).

Proses fotosintesis telah berjaya mendorong dan memberi inspirasi kepada saintis hari ini mencipta pelbagai teknologi bermula dengan sel suria terpeka pewarna (DSSC) (Grätzel 2003), diikuti oleh sel suria organik/polimer (OSC) (Günes et al. 2007) dan mutakhir ini sel suria perovskit (PSC) yang telah menggabungkan bahan organik dan bukan organik sehingga mampu mencapai kadar kecekapan yang tertinggi setakat ini (Zhou et al. 2014). Ini dilakukan dengan memanfaatkan julat tenaga tertentu yang terdapat pada sinaran matahari untuk menguja elektron daripada aras valensi ke aras konduksi. Sebelum ini Jan Ingenhousz berjaya membuktikan secara saintifik hasil kajiannya, dan menyatakan al-Qur'an telah menceritakan perihal proses fotosintesis ini seperti dalam ayat 35 surah an-Nur (Ballazi 2013).

\section{SEL SURIA TERPEKA PEWARNA (DSSC)}

Selain daripada menjadi sumber tenaga yang bersih, matahari membekalkan tenaga secara berterusan ke permukaan bumi. Kepentingan tenaga suria dalam menjana tenaga elektrik dapat dilihat penggunaannya dalam peranti elektronik seperti sel suria. Sel suria terpeka pewarna (DSSC) merupakan sebuah peranti yang terdiri daripada tiga komponen iaitu anod, elektrolit dan katod yang diapit antara substrat. Penghasilan anod dan katod bagi kebanyakan sel suria menggunakan substrat kaca yang konduktif sebagai tapak sebelum lapisan-lapisan lain dienapkan di atasnya. Bagi DSSC, semikonduktor seperti $\mathrm{TiO}_{2}$ lazimnya digunakan pada bahagian anod. $\mathrm{TiO}_{2}$ ini akan direndam di dalam pewarna seperti N719. Fungsi pewarna adalah menyerap cahaya matahari seperti klorofil pada daun. Pewarna N719 adalah pewarna komersial yang lazim digunakan dan telah mencatatkan nilai kecekapan sel suria DSSC yang tinggi hampir $11-12 \%$ kerana boleh menyerap cahayatampak sehingga cahaya inframerah (Buscaino et al. 2008; Chiba et al. 2006). Prinsip kerja sel suria bermula apabila foton daripada cahaya matahari menjanakan eksiton atau dikenali sebagai pasangan elektron-lohong. Eksiton ini perlulah dipisah kepada elektron dan 
lohong menggunakan tenaga daripada cahaya matahari seperti yang ditunjukkan pada Rajah 1. Dalam DSSC, foton daripada cahaya matahari akan memberikan tenaga kepada elektron dalam pewarna N719 dan $\mathrm{TiO}_{2}$ untuk bergerak ke luar litar. Selain berfungsi untuk memerangkap molekul pewarna, dan menyerap cahaya pada panjang gelombang $\mathrm{UV}, \mathrm{TiO}_{2}$ juga menyediakan laluan untuk pergerakan elektron dari anod $\left(\mathrm{TiO}_{2}\right.$ dan N719) kepada katod. Seterusnya, elektrolit yang mengandungi ion triodida ( $\left.\mathrm{I}^{-} / \mathrm{I}_{3}^{-}\right)$akan bertindak sebagai pengantara untuk merangkap elektron yang sampai pada katod dan menjana semula elektron yang telah teroksida di dalam pewarna (Alias \& Yaacob 2016; Mamat et al. 2018). Proses ini berlaku selagi sel suria ini disinari dengan cahaya. Pergerakan elektron inilah yang menghasilkan arus elektrik (Rajah 2).

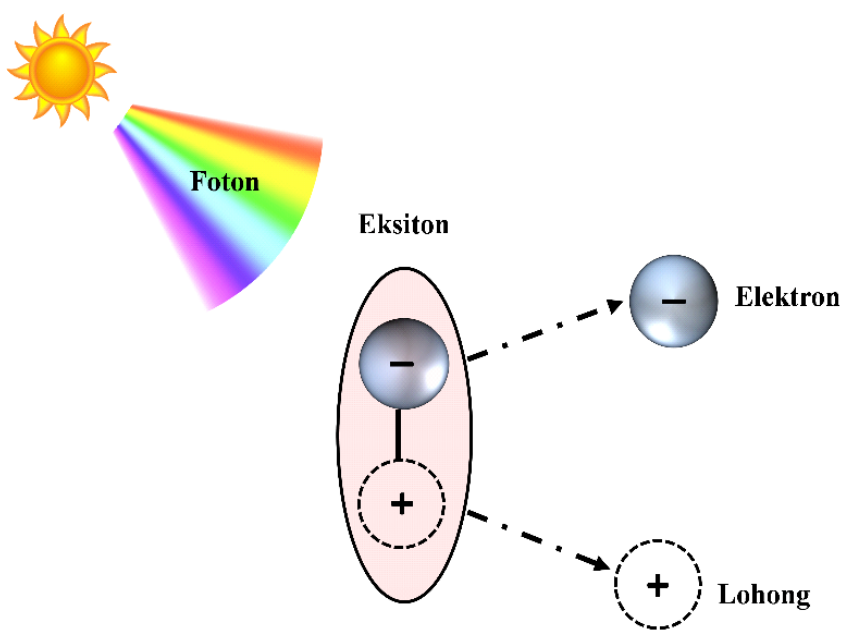

RAJAH 1. Proses pemisahan pasangan elektron-lohong akibat sinaran matahari

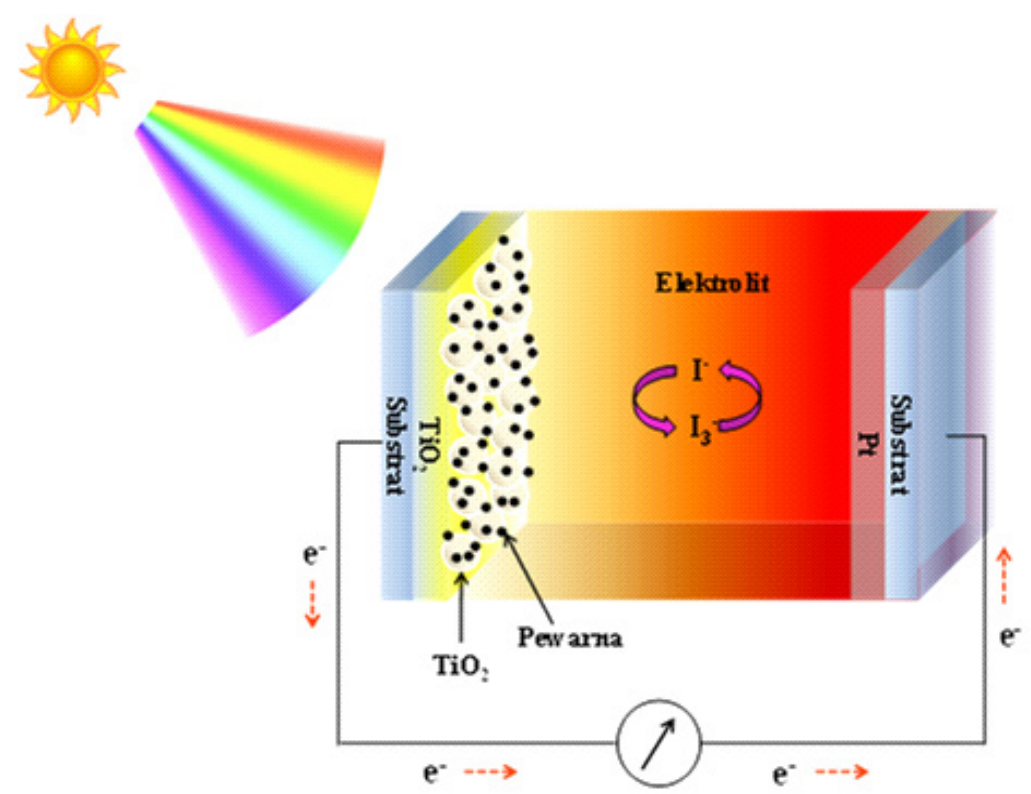

RAJAH 2. Struktur sel suria terpeka pewarna apabila disinari matahari 


\section{SEL SURIA ORGANIK (OSC)}

Sejak berdekad yang lalu, saintis telah melakukan kajian yang mendalam untuk menghasilkan sel suria menggunakan bahan organik. Penggunaan bahan organik dapat mengurangkan masalah alam sekitar sebab bahan organik tidak mencemarkan alam serta mengurangkan kos pembuatan. Umumnya, struktur sel suria organik terbahagi kepada dua iaitu heterosimpang dwi-lapisan dan heterosimpang pukal yang menggunakan bahan organik seperti polimer (Rajah 3). Sel suria heterosimpang dwilapisan mempunyai dua lapisan yang saling bersentuhan iaitu lapisan penerima elektron seperti PCBM dan penderma elektron seperti MEH-PPV. Kedua-dua lapisan ini dikenali sebagai lapisan aktif yang berfungsi untuk menyerap cahaya dan lapisan tersebut diapit oleh anod $\left(\mathrm{TiO}_{2}\right)$ dan katod $(\mathrm{Au})$ bagi mewujudkan pengaliran elektron. Elektron digunakan untuk mengalir elektrik dalam peranti ini (Yun \& Sulaiman 2011). Kegunaan emas telah dinyatakan secara jelas sebagai barang hiasan dalam surah Surah al-Kahfi (18); ayat 31, yang bermaksud,

'Mereka itu, disediakan baginya syurga yang kekal, yang mengalir di bawahnya beberapa sungai; mereka dihiaskan di dalamnya dengan gelang-gelang tangan emas, dan memakai pakaian hijau dari sutera yang nipis dan sutera tebal yang bersulam; mereka berehat di dalamnya dengan berbaring di atas pelamin-pelamin (yang berhias). Demikian itulah balasan yang sebaik-baiknya dan demikian itulah Syurga tempat berehat yang semolek-moleknya.'

Emas juga dijadikan barang tukaran yang paling berharga, seperti yang dinyatakan dalam Surah Ali-Imran (3); ayat 91, yang bermaksud,

'Sesungguhnya orang-orang yang kafir, lalu mati sedang mereka tetap kafir, maka tidak sekali-kali akan diterima dari seseorang di antara mereka: emas sepenuh bumi, walaupun ia menebus dirinya dengan (emas yang sebanyak) itu. Mereka itu akan mendapat azab seksa yang tidak terperi sakitnya, dan mereka pula tidak akan beroleh seorang penolong pun.'

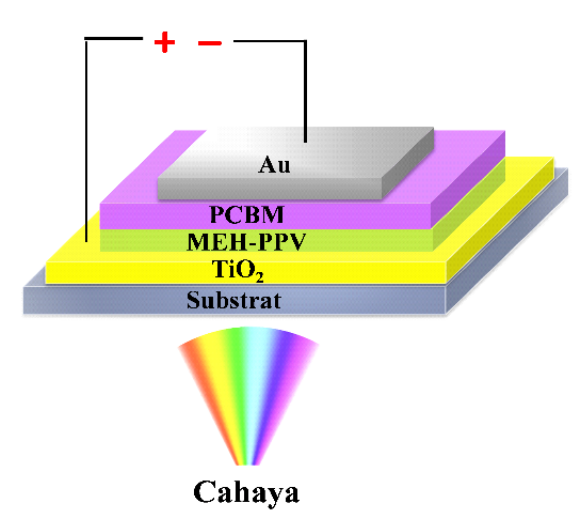

Sel suria heterosimpang
dwi-lapisan

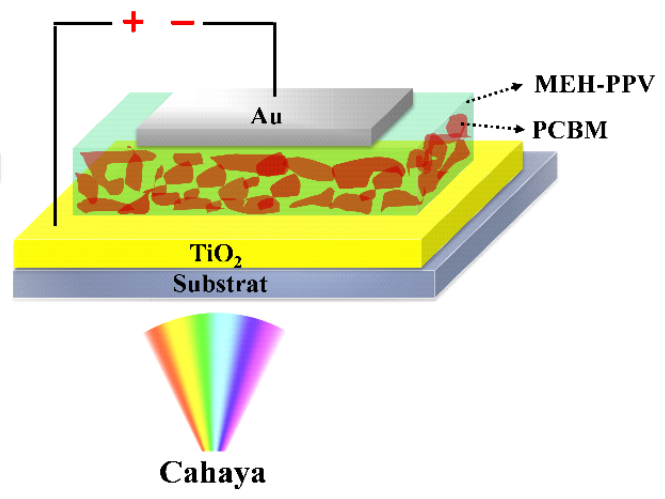

Sel suria heterosimpang pukal

RAJAH 3. Struktur sel suria heterosimpang dwi-lapisan dan heterosimpang pukal

Dari sudut sains, emas merupakan logam yang sangat fleksibel dan mudah dibentuk serta mempunyai ketumpatan yang tinggi. Kebanyakan kita menyangka logam emas diperoleh daripada kerak bumi, tetapi sebenarnya emas dihasilkan daripada pelakuran nuklear pada suhu yang sangat tinggi. Pelakuran nuklear melibatkan atom-atom hidrogen di angkasa bergabung dengan atom-atom lain seperti helium, karbon, oksigen dan nitrogen. Disebabkan suhu yang sangat tinggi sehingga satu tahap, letusan supernova berlaku dan kandungan atom-atom yang bergabung tadi dihambur ke serata cakerawala termasuklah emas. Emas mempunyai fungsi kerja tertentu yang membolehkan sebuah sel suria beroperasi dengan baik. Bermula daripada sinaran cahaya matahari, sel suria heterosimpang dwi-lapisan menyerap foton dan berlaku penjanaan eksiton pada lapisan penderma (MEH-PPV). Tenaga foton yang diperoleh diperlukan untuk memisahkan pasangan elektronlohong bagi membolehkan elektron bergerak ke litar dan menghasilkan arus elektrik. Namun begitu, pembikinan struktur dwi-lapisan ini lebih mencabar disebabkan kebanyakan eksiton yang dijana gagal untuk memasuki 
bahagian antara-muka penderma dan penerima (MEHPPV/PCBM). Hanya eksiton yang dijana berhampiran lapisan antara-muka (5-10 nm) akan mengalami pemisahan. Eksiton yang terjana pada kawasan yang lebih jauh akan menyebabkan elektron-lohong tadi bercantum semula (Mikhnenko et al. 2015) dan gagal untuk menghasilkan arus elektrik. Untuk menambahbaik kelemahan sel suria heterosimpang dwi-lapisan tadi, saintis telah memperkenalkan sel suria heterosimpang pukal yang mana lapisan penderma dan penerima dicampurkan bersama menjadi satu larutan sebelum dienapkan pada permukaan $\mathrm{TiO}_{2}$. Dengan langkah ini, pemisahan cas dalam heterosimpang pukal berlaku pada seluruh lapisan aktif berbanding dengan pemisahan cas dalam sel suria dwi-lapisan yang berlaku dalam kawasan antara-muka sehingga julat nanometer. Ini menjelaskan kecekapan penceraian eksiton adalah lebih tinggi pada jenis heterosimpang pukal.

\section{SEL SURIA PEROVSKIT (PSC)}

Struktur asas sel suria perovskit (PSC) ditunjukkan pada Rajah 4. Ia terdiri daripada substrat yang di atasnya dienapkan dengan lapisan pengangkutan elektron $\left(\mathrm{TiO}_{2}\right)$, diikuti lapisan perovskit, lapisan pengangkutan lohong (spiro-OMeTAD) dan katod (Au). Sel suria jenis ini berbeza dari segi bahan yang digunakan sebagai lapisan aktif yang menyerap cahaya. Berbanding dengan sel suria organik yang menggunakan polimer, bahan aktif sel suria PSC menggunakan campuran bahan organik dan bukan organik perovskit dengan formula kimia $\mathrm{ABX}_{3}$. A merupakan kation monovalen dan $\mathrm{B}$ kation divalen yang berlainan saiz dengan saiz A lebih besar daripada $\mathrm{B}$. Sebagai contoh, $\mathrm{A}=\mathrm{CH}_{3} \mathrm{NH}^{3+}, \mathrm{CH}\left(\mathrm{NH}_{2}\right)^{2+}, \mathrm{Cs}^{+} ; \mathrm{B}=\mathrm{Pb}^{2+}$, $\mathrm{Sn}^{2+}$. Manakala $\mathrm{C}$ pula monovalen daripada kumpulan halida seperti $\mathrm{Cl}, \mathrm{Br}$, dan I (Xie et al. 2019). Semasa PSC disinarkan oleh cahaya matahari, lapisan perovskit terlebih dahulu menyerap foton untuk menghasilkan pasangan elektron-lohong. Pasangan elektron-lohong ini perlu dipisahkan supaya elektron bergerak ke $\mathrm{TiO}_{2}$ dan lohong ke spiro-OMeTAD. Elektron yang dipindahkan dari bahan perovskit ke $\mathrm{TiO}_{2}$ akhirnya terkumpul di substrat. Pada masa yang sama, lohong daripada bahan perovskit dipindahkan ke spiro-OMeTAD terkumpul pada katod Au. Keseluruhan proses ini akan menghasilkan arus elektrik.

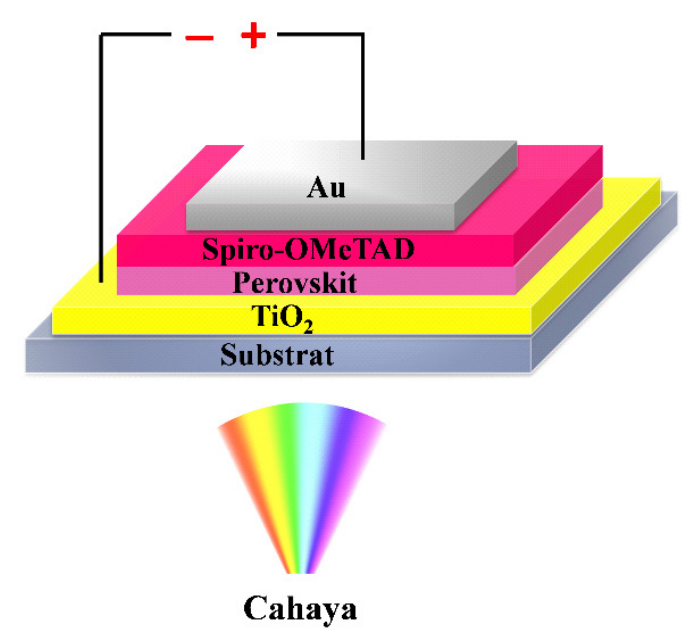

RAJAH 4. Sel suria perovskit

Kekuasaan Allah S.W.T. terbukti daripada sekecilkecil proses dalam skala nano sehinggalah terhasilnya tenaga elektrik yang merupakan aturan daripada-Nya. Proses penukaran tenaga matahari kepada tenaga elektrik dengan menggunakan peranti sel suria ini memberi manfaat kepada seluruh alam. Semua nikmat yang Allah berikan adalah percuma dan tidak dipengaruhi oleh mana-mana kuasa lain kerana Allah adalah pemilik mutlak, pemelihara dan pentadbir alam seperti dalam firman-Nya dalam surah al-Fatihah (1); ayat 2, yang bermaksud,

'Segala puji tertentu bagi Allah, Tuhan yang memelihara dan mentadbirkan sekalian alam.' 


\section{MATAHARI DALAM AL-QUR'AN}

Selain al-Qur'an menerangkan tentang kepentingan sinaran matahari kepada alam, terdapat sekurangkurangnya 13 ayat lain yang khusus berkaitan dengan matahari dalam al-Qur'an. Ini menunjukkan bahawa matahari mempunyai kepentingannya yang tersendiri, berbanding dengan penciptaan yang lain. Penerangan al-Qur'an tentang matahari memberi petunjuk dan penekanan kepada manusia bahawa dengan mencerap dan mengkaji tabii matahari, manusia akan beroleh manfaat dalam kehidupan mereka setiap hari.

Antara fungsi utama penciptaan matahari adalah untuk memberikan cahaya atau sinaran matahari. Tanpa cahaya matahari tidak mungkin manusia dapat melihat objek yang berada di sekitar mereka. Malah manusia di bumi tidak mungkin dapat menikmati keindahan sinaran bulan di waktu malam tanpa cahaya daripada matahari. Mataharilah yang memberikan sinarannya sehingga manusia dapat menilai kepentingan masa (Kopal 1996).

Sebelum manusia dapat menentukan masa dengan melihat jam seperti hari ini, aktiviti manusia dilaksanakan bergantung kepada suasana gelap dan cerah di sesuatu kawasan. Pada waktu siang yang diterangi oleh cahaya matahari, manusia bekerja. Pada waktu malam yang gelap, akibat ketiadaan cahaya matahari, manusia berehat. Begitu juga dengan sebahagian daripada aktiviti binatang, unggas dan tumbuhan yang lain.

Dalam al-Quran, Allah S.W.T. menyatakan tentang penciptaan masa dengan jelas sebagaimana firman-Nya dalam surah al-An'am (6); ayat 96 yang bermaksud,

'Allah jualah yang membelah cahaya subuh (yang menyingsingkan fajar), dan yang menjadikan malam untuk tinggal berehat, dan menjadikan matahari dan bulan untuk mengira waktu (menurut peredarannya). Yang demikian itu adalah kuasa penentuan Allah Yang Maha Kuasa, lagi Maha Mengetahui.'

Perhitungan malam dan siang atau pengkelasan masa ini tidak hanya sekadar pertukaran atau peralihan hari. Manusia primitif pernah mengukur masa berdasarkan kepada unit musim seperti musim sejuk, musim bunga, musim panas dan musim daun luruh. Ini disebabkan dalam setahun, dunia mempunyai empat musim yang berbeza (Soon et al. 2003). Dengan perbezaan musim ini, manusia mengatur aktiviti pertanian mereka berdasarkan kepada musim yang telah ditentukan Allah S.W.T. kepada mereka.

Hari ini masa di dunia dibahagikan dalam unit tahun. Dalam satu tahun terdapat 12 bulan. Setiap bulan mempunyai bilangan hari yang berbeza antara 28, 29, 30 atau 31 hari. Dalam satu tahun, bilangan harinya berjumlah 365 atau 366 hari. Perkiraan unit untuk masa ditentukan sama ada hari, minggu, bulan atau tahun (NPL 2014).
Penentuan unit masa (hari, minggu, bulan atau tahun) tersebut berkait rapat dengan cahaya matahari yang dilihat dari bumi. Satu putaran bumi dipaksinya, yang dilihat dari bumi dari terbit fajar pagi ini sehingga ke fajar hari berikutnya, dinamakan satu hari. Satu putaran bulan mengelilingi bumi, yang dilihat dari anak bulan ke anak bulan berikutnya, dinamakan satu bulan. Manakala satu persedaran bulan dan bumi (bulan mengelilingi bumi, dan bulan dan bumi mengelilingi matahari) mengelilingi matahari, yang dilihat dari bumi dari musim sejuk ke musim sejuk berikutnya, dinamakan satu tahun. Satu minggu pula merupakan bilangan selama 7 hari dari hari Jumaat (atau hari apa sahaja), ke hari Jumaat (atau hari apa sahaja) berikutnya (NPL 2014).

Bulan pula tidak mengeluarkan cahaya. Ini bererti di bulan tidak berlaku tindak balas nuklear sebagaimana yang berlaku pada matahari. Bulan hanya membalikkan cahaya daripada matahari yang kemudiannya menimpa bumi. Di bumi bulan kelihatan 'bercahaya' sebagaimana yang dinyatakan dalam ayat sebelum ini, akibat daripada sinaran matahari dibalikkan oleh bulan dan menimpa bumi. Ini bererti tanpa cahaya matahari yang menimpa bulan, dan kemudiannya dibalikkan ke bumi, bulan tidak mungkin dapat dilihat dari bumi (Kopal 1996).

Peredaran bumi dipaksinya, peredaran bulan mengelilingi bumi, dan peredaran bumi dan bulan mengelilingi matahari, semuanya membolehkan manusia menghitung hari, bulan dan tahun. Kehidupan di bumi yang berlaku akibat daripada peredaran ini akan menghasilkan musim-musim tertentu (sejuk, bunga, panas dan daun luruh) yang boleh digunakan oleh manusia untuk melakukan aktiviti pertanian. Ada faedah lain lagi seperti berlakunya fenomena air pasang surut akibat daya graviti yang mengikat bumi, bulan dan matahari (Nordgren 2016); dan juga berlaku peredaran udara (angin) yang membolehkan para pelayar menggunakan bahtera mereka sebagai sistem pengangkutan di laut. Binatang dan unggas yang lain juga memerlukan cahaya matahari untuk kehidupan mereka.

Walaupun sifat matahari yang panas, terang dan cerah yang boleh 'menghidupkan' segala aktiviti di dunia ini, al-Quran juga menyatakan kepada kita dalam surah Taha (20); ayat 119, bahawa di syurga nanti sifat matahari yang sedemikian tidak ada lagi, sebagaimana firman-Nya:

'Dan sesungguhnya engkau juga tidak akan dahaga dalam Syurga itu, dan tidak akan merasa panas matahari.

Juga dalam surah al-Insan (76); ayat 13:

'Mereka berehat di dalam Syurga dengan berbaring di atas pelaminpelamin (yang berhias), mereka tidak nampak di situ adanya matahari (usahkan hawa panasnya), dan tidak juga merasai suasana yang terlampau sejuk.' 
Melalui ayat-ayat ini, al-Quran boleh difahami tentang sifat matahari yang menyinarkan tenaganya ke bumi yang menyebabkan suhu panas sehingga boleh dirasai oleh makhluk di bumi. Bahagian bumi yang ditimpa sinaran matahari akan menyebabkan suhu bahagian tersebut meningkat berbanding kawasan lain yang kurang menerima sinaran matahari. Fenomena ini boleh difahami dengan membandingkan perbezaan antara suhu pada waktu malam dengan suhu pada siang hari. Jarak di antara matahari dengan bumi menyebabkan makhluk di bumi menerima suhu yang seimbang dan sesuai dengan kehidupan mereka; tidak terlalu panas akibat jarak matahari yang terlalu dekat dengan bumi dan tidak terlalu sejuk kerana jarak matahari yang terlalu jauh dari bumi (Lübken et al. 2012). Dengan nikmat haba panas daripada matahari juga, manusia sebagai khalifah di muka bumi ini mampu untuk menukar tenaga haba panas menjadi sumber untuk kebaikan manusia dan alam keseluruhannya (Saunders \& Chapman 2004). Antara manfaat yang dapat diperoleh manusia daripada haba panas adalah seperti proses pengeringan makanan, herba, seramik dan fabrik, proses penyulingan air untuk mendapatkan air yang bersih dan penghasilan air panas untuk rumah kediaman di kawasan sejuk serta penjanaan turbin air panas daripada sinaran haba daripada matahari.

Dalam Surah Nuh (71); ayat 16, sekali lagi Allah S.W.T. berfirman yang bermaksud,

'Dan Ia menjadikan padanya bulan sebagai cahaya serta menjadikan matahari sebagai lampu (yang terang-benderang).'

Dalam ayat ini, Allah S.W.T. sekali lagi menerangkan tentang ciri matahari yang dapat mengeluarkan atau menjana sinaran cahaya, bagaikan lampu, untuk menerangi alam jagat raya di sekitarnya, manakala bulan kelihatan bercahaya akibat daripada pantulan cahaya daripada matahari ke atasnya. Ini bererti matahari menyinarkan tenaganya ke persekitaran termasuk di bumi ini. Hikmahnya adalah apabila sinaran matahari ini menerangi bumi manusia boleh bekerja, bergerak dari satu tempat ke tempat yang lain dengan mudah, belajar dan membuat segala aktiviti pada siang hari dan berehat pada waktu malam yang gelap.

Selain itu, sinaran matahari yang menerangi alam memberi pengajaran kepada manusia untuk mengetahui dan mengkaji fenomena tabii alam fizikal seperti kewujudan bentuk bulan yang berbeza setiap hari dari anak bulan sehingga ke bulan penuh dan kemudian bentuknya mengecil semula sehinggalah berakhir di hujung bulan. Begitu juga dengan fenomena kejadian gerhana bulan dan matahari (Nordgren 2016), kewujudan bayangbayang yang membolehkan manusia menentukan waktu tertentu, proses kejadian siang dan malam serta sinaran cahaya matahari terang dan gelap dan berubah setiap hari sepanjang tahun terutamanya apabila dicerap di kutub utara atau selatan (NPL 2014). Kesemua ini menuntut manusia memahami sifat dan ciri berkaitan cahaya matahari supaya manusia boleh memanfaatkan cahaya matahari untuk kehidupan mereka.

Apabila dikaji dengan teliti, tenyata matahari menyinarkan cahaya dengan spektrum cahaya yang amat luas, dari panjang gelombang yang sependek-pendeknya sehinggalah ke panjang gelombang yang sepanjangpanjangnya. Dengan kata lain, frekuensi sinaran matahari boleh berada pada julat yang amat rendah sehinggalah kepada frekuensi yang amat tinggi. Ia merangkumi sinaran yang membolehkan mata kita mengesannya yang disebut sebagai sinaran tampak sehinggalah kepada sinaran yang menyumbang kepada haba dalam julat gelombang infra-merah, yang julat gelombang yang amat pendek yang berada dalam julat ultra-ungu. Sebahagian daripada sinaran yang datang daripada matahari telah ditapis (diserap) oleh lapisan ozon yang ada di atmosfera bumi, agar ia tidak memberi kemudaratan kepada makhluk di bumi (Mohd Yusof \& Kamaruzzaman 2002).

Sinaran matahari yang berada dalam julat inframerah dapat digunakan untuk aktiviti pengeringan seperti pengeringan hasil pertanian, herba, fabrik dan juga bahan-bahan seramik yang diperlukan oleh manusia dan hidupan di alam ini. Malah dengan bantuan teknologi yang canggih ia juga boleh digunakan untuk memanaskan air untuk kegunaan di rumah kediaman dan juga untuk menghasilkan tenaga elektrik dalam proses terma. Manakala sinaran matahari yang dalam julat ultra-ungu, dengan bantuan teknologi tenaga suria dapat digunakan untuk menyahtoksid sebahagian larutan yang merbahaya kepada manusia. Ia juga digunakan untuk mematikan sebahagian bakteria yang terdapat dalam air sebelum ianya diminum atau digunakan oleh manusia. Selain daripada membolehkan manusia dan binatang yang lain melihat, sinaran matahari dalam julat gelombang tampak juga dapat digunakan untuk menjana elektrik melalui penggunaan sel suria atau dikenali juga dengan nama sel fotovoltan yang amat terkenal digunakan di seluruh dunia untuk menghasilkan tenaga elektrik yang mapan dan tidak mendatangkan kemudaratan kepada alam sekitar. Teknologi fotovoltan telahpun digunakan dengan meluas dalam membekalkan tenaga elektrik kepada ribuan satelit yang berada di angkasa raya (Mohd Yusof \& Kamaruzzaman 2002).

Dalam surah al-Anbiya' (21); ayat 33, Allah S.W.T. berfirman yang bermaksud,

'Dan Dia lah (Tuhan) yang telah menjadikan malam dan siang, serta matahari dan bulan; tiap-tiap satunya beredar terapung-apung di tempat edaran masing-masing (di angkasa lepas).' 
Ayat ini menjelaskan kepada kita bahawa jauh di luar dari bumi ini wujudnya bulan, matahari, planet dan pelbagai bintang lain yang banyak sekali bilangannya yang beredar dalam tempat edarannya (yakni orbit) tanpa mengalami perlanggaran yang menjejaskan ekosistem di angkasa raya. Kesemua bintang, planet dan objek lain di alam jagat raya tersebut mempunyai sistem dan tabiinya yang dapat dikaji oleh manusia. Dengan mengkaji peredaran bumi dalam ekosistem suria, kita dapat meramalkan keadaan cuaca dan pergerakan angin dan udara di permukaan bumi. Apabila ekosistem suria dan ekosistem di alam cakerawala berada dalam keadaannya yang seimbang, kerosakan dan kemusnahan ekosistem di alam ini tidak mungkin berlaku. Keyakinan ini membolehkan manusia hidup dan membangunkan peradaban di atas muka bumi tanpa rasa bimbang akan berlakunya ketidaklestarian alam. Allah S.W.T. berfirman yang bermaksud (al-Qamar (54); 49),

'Sesungguhnya Kami menciptakan tiap-tiap sesuatu menurut takdir (yang telah ditentukan).'

Dalam al-Mulk (67), ayat 3, Allah S.W.T. berfirman yang bermaksud,

'Dia lah yang telah mengaturkan kejadian tujuh petala langit yang berlapis-lapis; engkau tidak dapat melihat pada ciptaan Allah Yang Maha Pemurah itu sebarang keadaan yang tidak seimbang dan tidak munasabah; (jika engkau ragu-ragu) maka ulangilah pandangan (mu) - dapatkah engkau melihat sebarang kecacatan?'

Selain itu, peredaran bumi, bulan dan matahari yang bersistem dalam ekosistem di alam jagat raya ini memudahkan manusia untuk mengkaji fenomena di angkasa raya. Ini terbukti dengan pelbagai kejayaan manusia meneroka angkasa raya. Selain berjaya menjejakkan kaki di bulan, meletakkan stesen angkasa antarabangsa di angkasa raya serta meletakkan begitu banyak satelit di angkasa raya. Kini saintis berusaha untuk menjejakkan kaki di planet Marikh dalam usaha untuk memahami tabii alam jasmani jagat raya. Pengetahuan manusia tentang ciri matahari ini tidak hanya menyebabkan manusia dapat mengambil manfaat daripadanya, malahan membantu manusia berhadapan dengan musibah daripada matahari seperti kesan strok haba (Leon \& Bouchama 2015), selaran matahari (Zand et al. 1999), kemarau panjang (Wang et al. 2015) serta kebakaran hutan dan jerebu (Mohd Shahwahid \& Jamal 2006). Ini dapat dilihat dengan kejayaan manusia menghasilkan pelbagai ciptaan seperti sistem empangan (Saunders \& Chapman 2004), teknologi pembenihan awan (Mohd Shahwahid \& Jamal 2006), teknologi tenaga suria, sistem suria terma, sistem suria fotovoltan (Mohd Yusof \& Kamaruzzaman 2002), sistem komunikasi, penderiaan jarak jauh dan pelbagai bahan ubatan dan farmasi bagi mengatasi masalah yang diakibatkan oleh matahari. Selain sebagai sumber utama menumbuhkan tumbuh-tumbuhan, matahari juga berperanan untuk membesarkan dan menyuburkan tumbuh-tumbuhan serta melebatkan buah-buahan untuk dinikmati oleh makhluk di bumi.

Dalam surah al-Furqan (25), ayat 45, al-Quran juga ada merujuk kepada matahari dengan firman-Nya yang bermaksud,

'Tidakkah engkau melihat kekuasaan Tuhanmu? - bagaimana Ia menjadikan bayang-bayang itu terbentang (luas kawasannya) dan jika Ia kehendaki tentulah Ia menjadikannya tetap (tidak bergerak dan tidak berubah)! Kemudian Kami jadikan matahari sebagai tanda yang menunjukkan perubahan bayang-bayang itu.'

Apa yang kita fahami daripada ayat ini adalah kewujudan matahari yang menghasilkan bayang-bayang sesuatu objek. Dengan mempelajari dan mengkaji tabii bayang-bayang sesuatu objek (Hodgson 2005), manusia dapat menghasilkan pelbagai ciptaan yang memberi manfaat dan kemudahan kepada manusia (Mende et al. 2000). Dengan mengkaji arah pergerakan matahari dan bayang objek yang ditimpa oleh sinaran matahari, manusia dapat mencipta bangunan dengan lorong yang sempit supaya sinaran terus daripada matahari dapat dielakkan yang akan meningkatkan suhu dalam bangunan tersebut. Bangunan sebegini masih dapat dilihat di Maghribi, Mesir, Sepanyol, Libya dan negara-negara yang pernah dihuni oleh umat Islam sebelum ini (Radoine 2017). Manusia juga dapat mencipta pelbagai jenis pakaian, topi dan payung untuk mengelakkan daripada sinaran terus daripada matahari yang boleh menyebabkan barah kulit.

Antara penciptaan yang amat penting umat Islam kepada dunia adalah pembinaan jam suria (Casey Rand 2012). Jam suria adalah peranti yang digunakan oleh umat Islam untuk menentukan masuknya waktu solat Dzohor dan 'Asar. Ia diukur berdasarkan kepada bayang sesuatu objek yang terdedah kepada sinaran suria (AlHassani 2012). Masuknya waktu Dzohor ditakrifkan sebagai tergelincirnya bayang suatu objek apabila sinaran matahari menimpanya, manakala masuknya waktu 'Asr adalah apabila panjang bayang objek lebih panjang daripada panjang objek berkenaan (al-Khin et al. 1992). Dengan demikian peranti ini dicipta berdasarkan kepada kebolehannya mengesan bayang sesuatu objek. Di Universiti Qarawiyyin yang dibina sejak 859, universiti pertama di yusufdunia, alat ini masih terdapat di laman masjid universiti berkenaan sehingga ke hari ini untuk tatapan dan panduan para jemaah yang hadir ke masjid berkenaan untuk bersolat.

Daripada konsep bayang dan imej objek, Ibn Haytham (965-1041) telah berjaya mencipta kamera 
obscura. Ibn Haitham merupakan orang pertama (pengasas) yang mengasaskan ilmu optik. Bukunya yang terkenal yang bernama al-Manaazir (buku optik) yang selesai ditulis dalam tahun 1011 telah digunakan lebih daripada lima kurun sebagai buku teks di universiti. Daripada ciptaan beliau inilah teknologi kamera telah dihasilkan. Malah perkataan 'kamera' itu sendiri berasal daripada istilah 'qamar' dalam bahasa Arab yang bermaksud bilik. Bilik di sini dirujuk oleh al-Haitham kepada kotak hitam kecil yang berbentuk 'bilik' atau 'qamar', tempat imej daripada luar 'kotak' terbentuk (el-Gomati 2017). Teknologi kamera hari ini sudah amat canggih apabila sifat cahaya itu difahami dengan lebih terperinci lagi.

Selain itu, cahaya yang dibincangkan dalam ilmu optik, menjadi semakin canggih apabila sistem komunikasi tidak hanya digunakan dalam sistem peranti elektronik tetapi juga menggunakan sistem peranti optik seperti teknologi serabut optik. Teknologi serabut optik digunakan dengan meluas hari ini kerana gangguan isyarat yang berlaku kepada serabut optik amatlah rendah berbanding dengan gangguan isyarat yang berlaku dalam sistem peranti elektronik yang lain.

Al-Quran juga menyebut tentang matahari sebagai planet yang mempunyai cahaya yang sangat terang, sehingga boleh menerangi bumi pada waktu siang. Malah, bulan yang tidak bercahaya apabila ditimpa pancaran cahaya matahari, mampu membalikkan cahaya tersebut kepada bumi sehingga mampu menerangkan bumi di waktu malam. Begitulah pengajaran yang boleh diambil dari surah al-Furqan (25); ayat 61, yang bermaksud,

'Maha Berkat Tuhan yang telah menjadikan di langit, tempat-tempat peredaran bintang, dan menjadikan padanya matahari serta bulan yang menerangi.'

Begitu juga dengan Firman Allah S.W.T. dalam surah Nuh (71); ayat 16, yang bermaksud,

'Dan Ia menjadikan padanya bulan sebagai cahaya serta menjadikan matahari sebagai lampu (yang terang-benderang).'

Kedua-dua ayat ini menjadi sumber utama kepada manusia untuk memikirkan tentang tabii bulan, matahari dan bumi serta planet lain di angkasa raya. Allah S.W.T. berfirman dalam surah al-Ankabut (29); ayat 61, yang bermaksud,

'Dan sesungguhnya jika engkau (wahai Muhammad) bertanya kepada mereka (yang musyrik) itu: "Siapakah yang menciptakan langit dan bumi, dan yang memudahkan matahari dan bulan (untuk faedah makhluk-makhluk-Nya)?" Sudah tentu mereka akan menjawab: "Allah”. Maka bagaimana mereka tergamak dipalingkan (oleh hawa nafsunya daripada mengakui keEsaan Allah dan mematuhi perintahNya)?'
Daripada ayat ini, dapat kita fahami bahawa antara fungsi lain matahari yang dinyatakan oleh al-Qur'an adalah berkaitan dengan fitrah manusia. Fitrah manusia secara tabii dan saintifiknya mengakui terdapat kuasa khusus yang mencipta, mengatur dan menggerakkan matahari. Matahari dengan sendirinya tidak mampu menggerakkan dirinya sendiri. Manusia yang ikhlas dan jujur terhadap analisis saintifik, pasti akan mengaku bahawa di sana terdapat suatu 'kuasa' yang menggerakkan seluruh objek di angkasa raya. Kuasa tersebut adalah dari Yang Maha Berkuasa, yakni Allah S.W.T. Sebab itulah apabila ditanya kepada manusia, siapakah yang mencipta langit, bumi, matahari dan bulan? Secara fitrah dan analisis saintifik, manusia akan menjawab Allah yang berkuasa mencipta semua ciptaan tersebut. Ayat tersebut juga memberi peringatan kepada manusia supaya percaya dan yakin kepada kebenaran dan berusahalah untuk mengelakkan diri dari mengingkari kebenaran (al-Qaradawi 1979).

Seperti yang diterangkan sebelum ini, al-Qur'an menyebut tentang manfaat adanya matahari dan bulan yang menjadikan fenomena kejadian malam dan siang, yang bermanfaat kepada kehidupan manusia dan makhluk lain. Dalam ayat ini pula, al-Qur'an menegaskan bahawa kesemua kejadian tersebut berserta dengan manfaatnya terjadi sepertimana yang ditentukan oleh Allah S.W.T. Matahari dan bulan, yang bergerak pada paksi masingmasing, taat dan patuh dengan perintah dan peraturan Allah S.W.T. Tidak sedikitpun mereka terkeluar dari landasan (orbit) masing-masing. Malah semua kejadian tersebut bergerak dalam kadar waktu dan kecepatannya yang tersendiri; tidak lebih atau kurang seperti yang telah ditetapkan oleh Allah S.W.T., yang dikenali pada hari ini sebagai sunnatullah (ketentuan Ilahi). Jika dilihat dari sudut ukuran jarak dan masa serta tenaga yang terlibat, kesemua sunnatullah tersebut jelas kelihatan sangat seimbang, sempurna dan begitu harmoni sekali.

Fenomena ini juga menyatakan kepada kita bahawa matahari, bulan dan semua kejadian di alam jagat raya ini saling berkait antara satu dengan yang lain, serta mempunyai peraturan atau hukum yang tertentu yang dapat difahami oleh manusia. Ayat ini juga mendorong manusia untuk terus gigih dan giat mencari faedah dan manfaat lain (Ahmad Sunari 2009) yang terdapat pada penciptaan matahari dan bulan sebagaimana firman Allah S.W.T. dalam surah al-Zumar (39), ayat 5, yang bermaksud,

'Ia (Allah) menciptakan langit dan bumi dengan ada faedah dan gunanya yang sebenar; Ia pula menjadikan malam melingkari siang (dengan gelapnya), dan menjadikan siang melingkari malam (dengan cahayanya); dan Ia menjadikan matahari dan bulan beredar menurut perintahnya, - tiap-tiap satu dari keduanya, beredar untuk suatu masa yang telah ditetapkan. Ingatlah! Dia lah Yang Maha Kuasa, lagi Yang sentiasa Mengampuni.' 
Begitu juga dengan firman Allah S.W.T. dalam Surah al-Rahman (55), ayat 5, yang bermaksud,

'Matahari dan bulan beredar dengan peraturan dan hitungan yang tertentu.'

Kefahaman yang hampir sama dengan penerangan ayat ini terdapat dalam surah Luqman (31), ayat 29, yang bermaksud,

'Tidakkah engkau memerhatikan bahawa Allah memasukkan malam pada siang dan memasukkan siang pada malam (silih berganti), dan Ia memudahkan matahari dan bulan (untuk faedah makhluk-makhlukNya)? Tiap-tiap satu dari keduanya beredar untuk suatu masa yang telah ditetapkan. Dan (ingatlah) sesungguhnya Allah Maha Mengetahui dengan mendalam akan apa yang kamu lakukan.'

Al-Qur'an sebagai kitab yang memberikan panduan kepada seluruh manusia telah memberikan pengajaran kepada manusia bahawa matahari yang diciptakan oleh Allah S.W.T. seolah-olah sebuah lampu yang terangbenderang cahayanya. Maka manusia yang mempunyai akal telah berjaya mengambil manfaat daripada cahaya matahari untuk membantu urusan kehidupan seharian mereka. Dengan memahami sifat cahaya matahari, manusia dapat mencipta sesuatu yang dapat membantu mereka untuk melihat di dalam suasana gelap. Analogi matahari sebagai lampu boleh difahami daripada firman Allah S.W.T. dalam surah al-Naba' (78), ayat 13, yang bermaksud,

'Dan Kami telah mengadakan matahari menjadi lampu yang terangbenderang cahayanya?'

Bagi umat Islam, solat merupakan ibadah yang paling utama dan amat penting. Tetapi solat mempunyai syarat-syarat yang perlu dipatuhi. Antara syarat tersebut adalah solat perlu dilaksanakan dalam waktu tertentu yang telah ditentukan waktunya. Untuk menentukan waktu solat, umat Islam bergantung sepenuhnya kepada peredaran matahari bagi menentukan waktunya (alKhin et al. 1992). Perkara ini diterangkan oleh al-Quran melalui surah al-Isra' (17), ayat 78 yang bermaksud,

'Dirikanlah olehmu sembahyang ketika gelincir matahari hingga waktu gelap malam, dan (dirikanlah) sembahyang subuh sesungguhnya sembahyang subuh itu adalah disaksikan (keistimewaannya).'

Selain itu, terdapat juga ibadah lain yang berkait rapat dengan kewujudan matahari. Ibadah puasa, zakat fitrah dan haji adalah ibadah yang ditentukan waktunya untuk dilaksanakan. Oleh yang demikian, masyarakat Islam perlu menentukan dengan pasti kehadiran bulan Ramadhan untuk melakukan ibadah puasa. Dalam bulan ini juga umat Islam diwajibkan mengeluarkan zakat fitrah, manakala fardzu haji perlu dipastikan mereka yang akan mengerjakan haji perlu berada di Padang Arafah sebelum masuknya waktu dzohor pada 9 Zulhijjah. Ini semuanya memerlukan umat Islam mengetahui pergerakan bulan (al-Khin et al. 1992). Untuk menentukan waktu-waktu penting tersebut, umat Islam memerlukan kepada pengetahuan dan kefahaman yang jelas tentang pergerakan bulan, bumi dan matahari.

\section{KESIMPULAN}

Al-Qur'an jelas menceritakan tentang tabii matahari dan hubung kaitnya dengan ciptaan lain di alam semesta ini. Manusia perlu terus berusaha untuk memahami tabii matahari supaya boleh memanfaatkan matahari dalam kehidupan mereka. Selain memberi manfaat kepada manusia, dengan memahami tabii matahari manusia dapat mengelakkan kesan negatif daripada sinaran cahaya matahari. Al-Qur'an turut menerangkan tentang tabii matahari untuk memudahkan orang Islam beribadat kepada Allah dengan sempurna. Seperti ibadah solat, puasa, zakat dan haji yang berkait rapat dengan pergerakan matahari. Keterangan al-Qur'an tentang matahari adalah sebagai panduan untuk manusia berfikir tentang penciptaan matahari itu sendiri; siapa penciptanya dan diikuti dengan penerimaan, dan pengakuan oleh manusia terhadap pencipta matahari tersebut iaitu Allah S.W.T.

Memahami peredaran matahari, bumi dan bulan, sinaran yang dihasilkannya membolehkan manusia memanfaat matahari. Aktiviti pertanian yang dijalankan pada sesuatu musim memerlukan pemahaman petani kepada keamatan sinaran suria di sesuatu lokasi. Bentuk sinaran suria dan akibatnya yang menyebabkan pergerakan angin yang beredar di muka bumi membolehkan manusia untuk meramal keadaan cuaca pada sesuatu hari. Sinaran infra merah yang menimpa bumi membolehkan manusia untuk membina teknologi terma suria seperti membekalkan air panas di rumah kediaman dan kilang-kilang, udara panas untuk proses pengeringan pelbagai produk. Kesan sinaran suria, terutamanya sinaran tampak, kepada bahan (terutamanya bahan semikonduktor) membolehkan manusia untuk membangunkan teknologi fotovoltan, suatu teknologi untuk menukarkan tenaga suria kepada tenaga elektrik. Tindak balas kimia yang diakibatkan oleh sinaran matahari kepada bahan-bahan membolehkan manusia membina pelbagai peranti yang dapat digunakan dalam kehidupan manusia. Begitu juga teknologi angkasa raya yang bergantung kepada proses kegravitian membolehkan manusia mencipta pelbagai alat yang dapat membantu manusia dalam kehidupan seharian mereka. Pendek kata, sekiranya kita tidak memahami ciri-ciri matahari kita akan ditinggalkan oleh mereka 
yang menguasai ilmu yang dapat memahamkan mereka dengan ciri-ciri yang terdapat pada matahari.

\section{PENGHARGAAN}

Penulis ingin merakamkan setinggi-tinggi penghargaan kepada Universiti Kebangsaan Malaysia yang membolehkan kertas ini ditulis di bawah pembiayaan dana penyelidikan GGP-2019-028 dan DIP-2018-009.

\section{RUJUKAN}

Abdullah Basmeih. 2010. Tafsir Pimpinan ar-Rahman Kepada Pengertian al-Qur'an. Putrajaya: JAKIM.

Abdus Salam 1995. Islam and science-concordance or conflict? Review of Religions 81(8): 1-12.

Ahmad Sunari Long. 2009. Pengenalan metodologi penyelidikan pengajian islam. Bangi: Jabatan Usuluddin dan Falsafah, Fakulti Pengajian Islam, Universiti Kebangsaan Malaysia (Tidak diterbitkan).

Al-Hassani, S.T. 2012. 1001 Inventions: The Enduring Legacy of Muslim Civilization. Washington: National Geographic Society. hlm. 156-203.

Alias, N.N. \& Yaacob, K.A. 2016. Natural dye sensitizer in dye sensitized solar cell. Sains Malaysiana 45(8): 1227-1234.

al-Khin, M., al-Bugha, M. \& al-Sharbaji, A. 1992. Al-fiqh almanhaji ala madhhab al-Imam al-Shafie. Dimashq: Dar al-Qalam.

al-Qaradawi Yusuf. 1979. Al-Iman wa al-Hayat. Beirut: Muassasah al-Risalah.

Ballazi, N.J. 2013. Penentuan tarikh-tarikh penting dalam sirah Rasulullah SAW berdasarkan pengiraan takwim Hijri terkini. Universiti Malaya. Tesis Dr. Fal. (Tidak diterbitkan).

Buscaino, R., Baiocchi, C., Barolo, C., Medana, C., Grätzel, M., Nazeeruddin, M.K. \& Viscardi, G. 2008. A mass spectrometric analysis of sensitizer solution used for dye-sensitized solar cell. Inorganica Chimica Acta 361(3): 798-805.

Chiba, Y., Islam, A., Watanabe, Y., Komiya, R., Koide, N. \& Han, L. 2006. Dye-sensitized solar cells with conversion efficiency of $11.1 \%$. Japanese Journal of Applied Physics 45(25): 638-640.

el-Gomati, M. 2017. Ibn al-haytham and the international year of light his legacy. Dlm Light-Based Science: Technology and Sustainable Development, The Legacy of Ibn al-Haytham, disunting oleh Boudrioua, A., Rashed, R. \& Lakshminarayanan, V. Florida: CRC Press. hlm. 148-162.

Grätzel, M. 2003. Dye-sensitised solar cells. Journal of Photochemistry and Photobiology C: Photochemistry Reviews 4(2): 145-153.

Günes, S., Neugebauer, H. \& Sariciftci, N.S. 2007. Conjugated polymer-based organic solar cells. Chemical Reviews 107(4): 1324-1338.

Hodgson, L. 2005. Making the Most of Shade: How to Plan, Plant, and Grow a Fabulous Garden that Lightens Up the Shadows. Pennsylvania: Rodale. hlm. 89-114.

Kopal, Z. 1996. An Introduction to the Study of the Moon. Netherlands: Springer. hlm. 321-434.

Leon, L.R. \& Bouchama, A. 2015. Heat stroke. Comprehensive Physiology 5(2): 611-647.
Lübken, F.J., Berger, U., Kiliani, J., Baumgarten, G. \& Fiedler, J. 2012. Variabality and trend effects in mesospheric ice layer. Dlm Climate and Weather of the Sun-Earth System (CAWSES): Highlights from a Priority Program, disunting oleh Lübken, F. Heidelberg: Springer Science \& Business Media. hlm. 317-338.

Magiels, G. 2010. From Sunlight to Insight: Jan Ingenhousz, the Discovery of Photosynthesis \& Science in the Light of Ecology. Brussels: VUBPRESS Brussels University Press. hlm. 357-366.

Mamat, S., Faizzi, M., Su'ait, M.S., Ludin, N.A., Sopian, K., Dzulkurnain, N.A., Ahmad, A., Shyuan, L.K., Khnoon, L.T. \& Brandell, D. 2018. Kajian elektrolit polimer berasaskan getah asli terubah suai (MG49) dalam sel suria terpeka pewarna. Sains Malaysiana 47(11): 2667-2676.

Medawar, P.B. 1987. The Limits of Science. Oxford: Oxford University Press. hlm. 84-146.

Mende, K., Mende, K. + Lighting Planners Associates (Firm), Lighting Planners Associates Inc. 2000. Designing with Light and Shadow. Victoria: Images Publishing. hlm. 10-14.

Mikhnenko, O.V., Blom, P.W. \& Nguyen, T.Q. 2015. Exciton diffusion in organic semiconductors. Energy \& Environmental Science 8(7): 1867-1888.

Mohd Shahwahid, H.O. \& Jamal Othman 2006. Malaysia. Dlm. Indonesia's Fires and Haze: The Cost of Catastrophe, disunting oleh Glover, D. \& Jessup, T. Singapore: Institute of Southeast Asian Studies. hlm. 22-50.

Mohd. Yusof Haji Othman \& Kamaruzzaman Sopian. 2002. Teknologi Tenaga Suria. Bangi: Penerbit Universiti Kebangsaan Malaysia.

NewPath Learning (NPL). 2014. The Sun-Earth-Moon System Science Learning Guide. New York: NewPath Learning. hlm. 2-17.

Nordgren, T. 2016. Sun Moon Earth: The History of Solar Eclipses from Omens of Doom to Einstein and Exoplanets. Basic Books. hlm. 112-147.

Radoine, H. 2017. Architecture in Context: Designing in the Middle East. West Sussex: John Wiley \& Sons. hlm. 1-52.

Rand, C. 2012. Time. London: Raintree. hlm. 12-17.

Saunders, N. \& Chapman, S. 2004. Renewable Energy. Oxford: Raintree. hlm. 29-35.

Soon, W.W.H. \& Yaskell, S.H. 2003. The Maunder Minimum and the Variable Sun-Earth Connection. Singapore: World Scientific Publishing Co. Pte. Ltd. hlm. 85-96.

Wang, Q.F., Wu, J.J., Geng, G.P., Zhou, H.K. \& Mo, X.Y. 2015. Variability and patterns of drought characteristics based on SPEI in the Huang-Huai-Hai plain between 1981 and 2010. Dlm. Research and Science-Policy Interfacing, disunting oleh Andreu, J., Abel Solera, Paredes-Arquiola, J., HaroMonteagudo, D. \& Drought, H.V.L Leiden: CRC Press. hlm. 187-192.

Xie, J., Liu, F. \& Yan, K. 2019. Perovskite solar cells processed by solution nanotechnology. Dlm. Advanced Nanomaterials for Solar Cells and Light Emitting Diodes, disunting oleh Gao, F. Netherland: Elsevier. hlm. 119-174.

Yun, T.W. \& Sulaiman, K. 2011. Fabrication and morphological characterization of hybrid polymeric solar cells based on P3HT and inorganic nanocrystal blends. Sains Malaysiana 40(1): 43-47. 
Zain, S.M. 2000. Pengenalan Sejarah dan Falsafah Sains. Bangi: Penerbit Universiti Kebangsaan Malaysia.

Zand, J., Spreen, A.N. \& LaValle, J.B., 1999. Smart Medicine for Healthier Living. New York: Avery Publishing Group. hlm. 544-545.

Zhou, H., Chen, Q., Li, G., Luo, S., Song, T.B., Duan, H.S., Hong, Z., You, J., Liu, Y. \& Yang, Y. 2014. Interface engineering of highly efficient perovskite solar cells. Science 345(6196): $542-546$

Muhammad Hilmi Jalil, Mohammad Ikhwan Ismail \& Mohd Yusof Haji Othman* Institute of Islamic Hadhari

Universiti Kebangsaan Malaysia

43600 UKM Bangi, Selangor Darul Ehsan

Malaysia
Siti Nur Farhana Mohd Nasir \& Mohd Asri Mat Teridi Solar Energy Research Institute (SERI)

Universiti Kebangsaan Malaysia

43600 UKM Bangi, Selangor Darul Ehsan

Malaysia

*Pengarang untuk surat menyurat; email: myho@ukm.edu.my

Diserahkan: 7 Ogos 2020

Diterima: 19 Ogos 2020 